DOI https://doi.org/10.18551/rjoas.2020-12.09

\title{
THE ROLE OF TRUST IN MEDIATING THE EFFECT OF PERCEIVED RISK AND SUBJECTIVE NORM ON CONTINUOUS USAGE INTENTION ON GOPAY USERS IN DENPASAR
}

\author{
Rahmayanti Putu Laksmita Dewi ${ }^{\star}$, Rahyuda I Ketut \\ Faculty of Economics and Business, University of Udayana, Bali, Indonesia \\ ${ }^{*}$ E-mail: laksmita72@gmail.com
}

\begin{abstract}
The purpose of this study was to explain the effect of perceived risk and subjective norms on belief and continuous usage intention, the effect of trust on continuous usage intention, and the role of trust in mediating the effect of perceived risk and subjective norm on continuous usage intention. The research subjects were GoPay users, with a sample of 140 people. The sample was determined using a non-probability sampling method, namely purposive sampling. The data were analyzed using SEM-PLS technique. The results of this study indicate that perceived risk has a negative and significant effect on continuous usage intention, subjective norm has a positive and insignificant effect on continuous usage intention, perceived risk has a negative and significant effect on trust, subjective norm has a positive and insignificant effect on trust, trust has a positive effect. and significant on continuous usage intention, and trust is able to mediate the influence of perceived risk and subjective norm on continuous usage intention. The practical implication that can be given from the findings of this study is that this study can be used as a basic model for evaluating the GoPay strategy on perceived risk, subjective norms, trust, and continuous usage intention. Based on the results of statistical data, among the three variables that influence continuous usage intention, the trust variable has the highest path coefficient, which can be a reference for GoPay management in making strategies to increase the continuous usage intention of its users by increasing its trust.
\end{abstract}

\section{KEY WORDS}

Perceived risk, subjective norm, trust, continuous usage intention, Go-Pay.

The Covid-19 pandemic affects people's lives, both in health and in social and economic aspects. This condition makes all Indonesians, even the world, make efforts to avoid exposure to the virus. Entering the new normal era, people will return to their normal activities, but with the implementation of strict health protocols. The same thing happened to shopping activities. Besides being able to avoid crowds or carry out physical distancing, online shopping can also minimize cash transactions. Many people avoid using cash as a means of payment at this time, because cash is one of the transmissions of the spread of Covid-19. To buy necessities, people can easily use the application and pay directly using ewallets.

The use of e-wallets offline also makes shopping more practical and efficient because transactions are very fast making it suitable for reducing cash usage during the new normal. Public support for cashless also supports the government in terms of financial and health inclusion during the Covid-19 pandemic. E-wallets in this case are all forms of server-based electronic wallets, not chip-based. Based on data from Bank Indonesia quoted from the iPrice online news website (2020), 38 e-wallets have received official licenses. In 2018, ewallet transactions in Indonesia reached USD 1.5 billion and is predicted to increase to USD 25 billion in 2023 (iPrice, 2020). Data obtained from the secondary data provider website Statistica (2020) states that $40 \%$ of e-wallet users in Indonesia use e-wallets to transact more than once a week.

One of the e-wallet services in Indonesia is GoPay, which is offered by the decacorn transportation service provider, Go-Jek. GoPay is one of the features found in the Go-Jek application which is an application of the digital payment system. Based on the January 2020 
article published on the online news website IDN Financials (2020), the gross transaction value of GoPay in 2019 was reported at US $\$ 6.3$ billion or around Rp.89.5 trillion, which is 70 percent of Go-Jek transactions using GoPay as the payment method. At first GoPay was only used as a payment medium for services in the Gojek application. Users can transact using GoPay both online and offline with various parties that work with GoPay. The gross transaction figure was obtained thanks to Go-Jek's cooperation with two million driver partners, 400 thousand merchants, 1.5 million agents and 600 thousand service providers. GoPay remains the leading e-wallet in Indonesia in terms of gross transaction value with nearly 61\% market share in Indonesia in 2019 online news site MoneyFazz (2020).

The number of monthly active users of GoPay is the largest in Indonesia according to research by the iPrice Group and AppAnnie quoted on the online news site Kata Data (2019), so that it can serve as an opportunity for marketers. Research conducted by Pinem (2020) states that $83 \%$ of respondents stated that they do not agree to replace the use of cash in transactions with Go-Pay because sometimes errors occur in Go-Pay which cause transactions to be blocked. Research conducted by Baraja and Gunawan (2020) also states that when users use Go-Pay to transact at merchants and customers accumulate, problems can arise in the transaction process due to frequent errors or network interruptions.

To get a direct picture of the use of e-wallets, especially Go-pay, a preliminary interview was conducted with 30 Go-pay users in Denpasar City. Based on the results of the preliminary interview, most of the respondents considered that their behavior to continue using GoPay was influenced by trust, perceptions of people around them, and the risks that users felt. There are negative issues that hit Go-Pay such as in terms of security and errors that occur can cause users not to use Go-Pay continuously because for users, perceived risks are considered by users in using Go-Pay. The perceptions of the people around you are also considered in the sustainability of users using Go-Pay, but due to the increasing number of new e-wallets emerging, the perceptions of people around users who use other e-swallow can affect the user's sustainability in using GoPay. Therefore, this can be a threat for GoPay to retain its users.

The success of an application can be seen from the behavior of its users in using the application, if the user continues to use the application, of course it will have a positive impact on the service provider company so that the service provider can continue to exist. One way to measure this is by looking at the user's intention to use an application on an ongoing basis or what is called continuous usage intention. Continuous usage intention refers to user behavior in continuous use of a product (Wang, 2016). Continuous usage intention of users is considered as a measure to evaluate the implementation of certain technologies (Zhou et al., 2012). Further research is needed to adopt a more appropriate model to understand continuous usage intention behavior rather than relying on traditional models (Nabavi et al., 2016).

When consumers make decisions, especially those concerning the use of technology applications, consumers will consider internal and external factors. One of the internal factors of consumers is their self-assessment of the risk of using these technology applications, which is known as percived risk. Especially threats in terms of authentication or verification of who enters the e-wallet system, because this is often used by hackers to hack e-wallet user accounts (Nguyen and Huynh, 2018). Users are also worried about an error in the e-wallet application that causes transactions to be delayed or canceled so that it can reduce their continuous use intention to use e-wallets (Rahman, 2014). Veeramootoo et al. (2018) argue that perceived risk greatly affects individual intentions to use online technology due to various uncertainties associated with the internet. Another study reports that perceived risk can negatively affect behavioral intentions in continuous use (Wang, 2016). Previous research has reported a negative and significant effect of perceived risk on continuous usage intention (Park and Oh, 2019; Wang, 2016; Wang and Lin, 2017), but research conducted by Hepola et al. (2016) stated that perceived risk has no significant effect on continuous usage intention.

The external factor that determines the consumer's decision is the opinion of others. One of the determinants of behavioral intention in TPB is subjective norm (Salleh and 
Laxman, 2015). Many studies have investigated this theory and found that this theory is capable of explaining individual intentions to use various forms of information technology and technology acceptance (Shiue et al., 2017). Subjective norm can be defined as a person's subjective belief that most other people think that he should (or shouldn't) behave in a certain way (Ho et al., 2017). Subjective norms are determined by the social pressure felt from others for someone to behave in a certain way and their motivation to comply with those people's views. The higher the perceived expectations of others, the stronger the subjective norms, and the stronger the subjective norms, the stronger the intention to perform the behavior (Hong, 2018). Individuals who hold subjective norms will be stimulated by the need for approval from significant others (Yang, 2019). Therefore, subjective norm is important to determine the user's continuous usage intention behavior.

GoPay had stumbled upon an issue related to hacking that caused consumers to lose their GoPay balance. This raises questions about the security of the system that e-wallets have in protecting their users. E-wallets involve many risks, both financial and non-financial, which can be caused by the lack of competence of service providers in protecting user confidentiality. Trust in service providers will decrease if unauthorized users can freely access other people's accounts, when personal information is leaked without their consent or when the information is provided for secondary use (Park and Oh, 2019). Therefore, if the perceived risk is high, it can ultimately result in the user having a decreased trust (Nakayama et al., 2016). This is supported by the research of Hong et al. (2015) and Nakayama et al. (2016) which states that perceived risk has a significant effect on trust. Previous research has also looked at how building trust has a direct impact on intentions to use and sustainable adoption of social media (Zhou and Li, 2014). According to research from Chang et al. (2017) and Wang and Lin (2017) state that trust in technology can influence sustainability intentions to use that technology, however findings in previous studies suggest that trust will not always have a positive influence on sustainable use because trust can positively affect long-term relationships. short but not long term relationship (Susanto et al., 2016). Therefore, trust is used in this study as a mediating variable for the relationship between subjective norm and perceived risk with continuous usage intention.

Continuous usage intention refers to user behavior in continuous use of a product (Wang, 2016). One of the internal factors of consumers is their self-assessment of the risk of using these technology applications, which is known as perceived risk. Perceived risk refers to negative results that are inconsistent with expectations that can occur in the process of using the application. Previous research has reported a negative and significant effect of perceived risk on continuous usage intention (Park and Oh, 2019; Wang, 2016; Wang and Lin, 2017), but research conducted by Hepola et al. (2016) stated that perceived risk has a negative and insignificant effect on continuous usage intention.

Generally, consumers will consider the comments, suggestions, or opinions of others who become their role models before using a product or their decision to keep using certain products, including the use of technology applications in payment. The higher the perceived expectations of others, the stronger the subjective norms, and the stronger the subjective norms, the stronger the intention to perform the behavior (Hong, 2018). Research by Goh (2017), Abdullatif et al. (2017), Wang and Chou (2016), Yoon and Rolland (2015) show a positive and significant relationship between subjective norms and continuous usage intention, but research conducted by Bagozzi and Lee (2002) and Yang (2019) states that subjective norm has no significant effect on continuous usage intention.

There are a number of research results that seem inconsistent on continuous usage intention which are explained by the variable perceived risk and subjective norm indicating the need for the presence of other variables. One of them is the variable trust or trust. Trust in service providers will decrease if unauthorized users can freely access other people's accounts, when personal information is leaked without their consent or when the information is provided for secondary use (Park and Oh, 2019). Therefore, if the perceived risk is high it can eventually result in the user having a decrease in trust. Previous research conducted by Abdul-Hamid et al. (2019), Chang et al. (2017), D'Alessandro et al. (2012), Hong et al. (2015) and Nakayama et al. (2016) give results that perceived risk has a negative and significant 
effect on trust, while research conducted by Nguyen and Huynh (2018) shows that perceived risk has a negative but not significant effect on trust.

Trust can arise as a result of the effect of the social environment (Bapna et al., 2017), so that in this study using subjective norms as one of the exogenous variables that affect trust. Previous research conducted by Beldad and Hegner (2018), Hitosugi (2011), Ho et al. (2017), and Kusumawardhani et al. (2019) stated that subjective norm has a positive and significant effect on trust. Research conducted by Gong et al. (2019) found that trust mediates the relationship between subjective norms and technology adoption. Research conducted by Salehan et al. (2013) stated that subjective norm has a positive but insignificant effect on trustworthiness. Users who trust an application tend to develop perceptions that can lead to the formation of long-term commitment and loyalty to an application. According to research from Wang et al. (2013), Hanafizadeh et al. (2014), Zhou and Li (2014), Yan and Yang (2015), Chang et al. (2017), and Wang and Lin (2017) state that trust has a positive and significant effect on continuous usage intention. However, the findings in the research of Susanto et al. (2016) stated that trust has a positive but insignificant effect on continuous usage intention. Based on this background, formulate the following hypothesis:

- H1: Perceived risk has a negative and significant effect on continuous usage intention;

- H2: Subjective norm has a positive and significant effect on continuous usage intention;

- H3: Perceived risk has a negative and significant effect on trust;

- H4: Subjective norm has a positive and significant effect on trust;

- H5: Trust has a positive and significant effect on continuous usage intention;

- H6: Trust is able to significantly mediate the effect of perceived risk on continuous usage intention;

- H7: Trust is able to significantly mediate the effect of subjective norms on continuous usage intention.

\section{METHODS OF RESEARCH}

This research uses a quantitative approach and is an associative study. The sampling method used is non-probability sampling, which is a sampling technique that does not provide equal opportunities for each element or member of the population to be selected as samples (Rahyuda, 2017: 172). The research was conducted in Denpasar City because according to data in the online news website Lokadata (2019), it was stated that the 2018 BPS National Socio-Economic Survey (Susenas), the largest internet penetration was centered on the islands of Java and Bali. The percentage of internet users in Bali (42.91 percent) is higher than in Java (40.29 percent). Denpasar is the city with the highest internet access. As many as 68 percent of the population has accessed the internet (Beritagar.id, 2019), so that it is effective and efficient as a relevant research location. The population in this study were all GoPay users in Denpasar City whose number could not be determined with certainty (infinite). This study uses 14 indicators so that the sample required is at least $70(5 \times 14)$ and a maximum of $140(10 \times 14)$. This study used 140 respondents, which are 14 indicators multiplied by 10 , which means they have met the criteria of a minimum of 70 respondents and a maximum of 140 respondents. This study uses 14 indicators so that the sample required is at least $70(5 \times 14)$ and a maximum of $140(10 \times 14)$. This study used 140 respondents, which are 14 indicators multiplied by 10 , which means that the minimum criteria for 70 respondents and a maximum of 140 respondents are met. The data analysis method used was descriptive statistical analysis and inferential statistical analysis which was analyzed with Smart-PLS software

\section{RESULTS AND DISCUSSION}

Based on the results of the characteristics of the respondents in this study, the dominant users were female than male, namely 86 people or 61.4 percent. This means that 
female users use GoPay more. The number of users aged 18-26 years was the most among the others, namely 105 people or 75.0 percent. This phenomenon states that users aged 1826 use GoPay the most. In this study, respondents when viewed from the perspective of the latest education, users with the latest $\mathrm{S} 1$ education were the most dominant among the others, namely 93 people or 66.4 percent. This phenomenon states that users who have a bachelor's degree use GoPay the most. Based on occupation, the most dominating users are students, as many as 57 people or 40.7 percent. This phenomenon states that users who are students or university students use GoPay the most

Table1 - Direct Effect Test Results

\begin{tabular}{|c|c|c|c|c|}
\hline & Path coefficient & t statistics & $P$ Values & Information \\
\hline Perceived Risk $\left(\mathrm{X}_{1}\right)$-> Continuous Usage Intention $\left(\mathrm{Y}_{2}\right)$ & -0.325 & 4.327 & 0.000 & Significant \\
\hline Subjective Norm $\left(\mathrm{X}_{2}\right)$-> Continuous Usage Intention $\left(\mathrm{Y}_{2}\right)$ & 0.020 & 0.064 & 0.750 & Not Significant \\
\hline Perceived Risk $\left(\mathrm{X}_{1}\right)->$ Trust $\left(\mathrm{Y}_{1}\right)$ & -0.625 & 13.767 & 0.000 & Significant \\
\hline Subjective Norm $\left(\mathrm{X}_{2}\right)$-> Trust $\left(\mathrm{Y}_{1}\right)$ & 0.193 & 2.330 & 0.020 & Significant \\
\hline Trust $\left(\mathrm{Y}_{1}\right)->$ Continuous Usage Intention $\left(\mathrm{Y}_{2}\right)$ & 0.520 & 6.775 & 0.000 & Significant \\
\hline
\end{tabular}

Source: Processed from primary data, 2020.

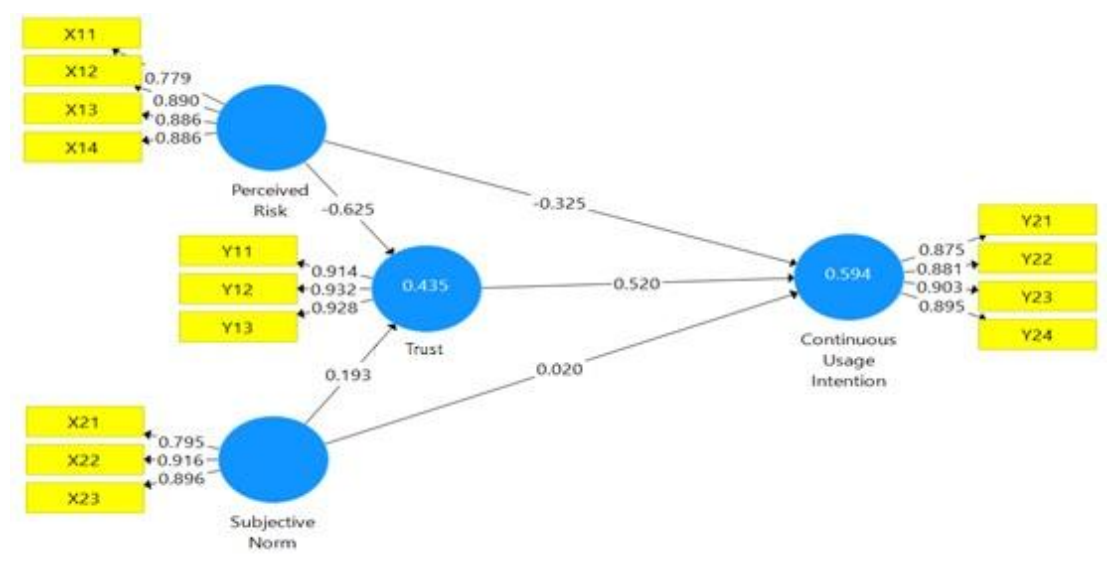

Figure 1 - Structural Model (Source: Processed from primary data, 2020)

Table 2 - Recapitulation of Test Results for Mediation Variables

\begin{tabular}{|c|c|c|c|c|c|}
\hline \multirow{2}{*}{ Variables } & \multicolumn{4}{|l|}{ Effect } & \multirow{2}{*}{ Information } \\
\hline & (A) & (B) & (C) & (D) & \\
\hline $\begin{array}{l}\text { Perceived risk (X1) -> Trust (Y1) -> Continuous usage } \\
\text { intention }(\mathrm{Y} 2)\end{array}$ & $\begin{array}{l}-0,325 \\
\text { (Sig.) }\end{array}$ & $\begin{array}{l}-0,325 \\
\text { (Sig.) }\end{array}$ & $\begin{array}{l}-0,625 \\
\text { (Sig.) }\end{array}$ & $\begin{array}{l}0,520 \\
\text { (Sig.) }\end{array}$ & $\begin{array}{l}\text { Partial } \\
\text { Mediation }\end{array}$ \\
\hline $\begin{array}{l}\text { Subjective norm (X2) -> Trust }(\mathrm{Y} 1)->\text { Continuous } \\
\text { usage intention }(\mathrm{Y} 2)\end{array}$ & $\begin{array}{l}0,101 \\
\text { (Sig.) }\end{array}$ & $\begin{array}{l}0,020 \text { (Non } \\
\text { Sig.) }\end{array}$ & $\begin{array}{l}0,193 \\
\text { (Sig.) }\end{array}$ & $\begin{array}{l}0,520 \\
\text { (Sig.) }\end{array}$ & $\begin{array}{l}\text { Full } \\
\text { Mediation }\end{array}$ \\
\hline
\end{tabular}

Source: Primary data processed, 2020.

Description: significance (Sig.) $=t$-statistic $>1,96$ on $a=5 \%$.

$A$ : indirect effect of exogenous variables ( $X 1$ or $X 2)$ on endogenous variables $(Y 1)$.

$B$ : direct effect of exogenous variables ( $X 1$ or $X 2)$ on endogenous variables (Y2).

$C$ : direct effect of exogenous variables ( $X 1$ or $X 2)$ on endogenous variables (Y1).

$D$ : direct effect of endogenous variables (Y1) on endogenous variables (Y2).

The effect of perceived risk on continuous usage intention. The results show that perceived risk has a negative and significant effect on continuous usage intention. This means that an increase in the perceived risk felt by GoPay users, leads to lower user's continuous usage intention and vice versa. These results indicate that the values contained in perceived risk have a significant impact on the continuous usage intention of GoPay users. Perceived risk which is measured based on indicators: leakage of transaction information, malfunctions, risk of losing money, and hacking as acceptable are proven to be able to influence the continuous usage intention of GoPay users. This finding can be interpreted that if users feel there is a risk of leaking transaction information, there is a risk of malfunction, there is a risk of losing money, and there is a risk of hacking, then this will be able to make a 
significant contribution in reducing continuous usage intention of GoPay users. The results of this study are in accordance with the results of previous studies by Chang et al. (2017) which gives results that perceived risk has a negative and significant effect on continuous usage intention. The results of this study also support research conducted by Park and Oh (2019) which states that increasing perceived risk can reduce the likelihood of continued user intentions. These results are also supported by research conducted by Wang (2016) and Wang and Lin (2017) which state that perceived risk has a negative and significant effect on continuous usage intention. The results of this study contradict research conducted by Hepola et al. (2016) stated that perceived risk has no significant effect on continuous usage intention.

Table 3 - Direct Effect, Indirect Effect, Total Variable Effect, and Calculation of VAF

\begin{tabular}{|c|c|c|}
\hline \multirow[t]{2}{*}{ Variable } & \multicolumn{2}{|l|}{ Direct Effect } \\
\hline & Coef. Correlation & t-Statistics \\
\hline Perceived Risk $\left(\mathrm{X}_{1}\right)$-> Continuous Usage Intention $\left(\mathrm{Y}_{2}\right)$ & -0.325 & 4.327 \\
\hline Subjective Norm $\left(\mathrm{X}_{2}\right)$-> Continuous Usage Intention $\left(\mathrm{Y}_{2}\right)$ & 0.020 & 0.064 \\
\hline Perceived Risk $\left(\mathrm{X}_{1}\right)->$ Trust $\left(\mathrm{Y}_{1}\right)$ & -0.625 & 13.767 \\
\hline Subjective Norm $\left(\mathrm{X}_{2}\right)->$ Trust $\left(\mathrm{Y}_{1}\right)$ & 0.193 & 2.330 \\
\hline Trust $\left(\mathrm{Y}_{1}\right)->$ Continuous Usage Intention $\left(\mathrm{Y}_{2}\right)$ & 0.520 & 6.775 \\
\hline \multirow[t]{2}{*}{ Variable } & \multicolumn{2}{|l|}{ Indirect Effect } \\
\hline & Coef. Correlation & $t$-Statistics \\
\hline Perceived Risk $\left(\mathrm{X}_{1}\right)$-> Trust $\left(\mathrm{Y}_{1}\right)$-> Continuous Usage Intention $\left(\mathrm{Y}_{2}\right)$ & -0.325 & 2.894 \\
\hline Subjective Norm $\left(\mathrm{X}_{2}\right)->$ Trust $\left(\mathrm{Y}_{1}\right)->$ Continuous Usage Intention $\left(\mathrm{Y}_{2}\right)$ & 0.101 & 3.382 \\
\hline \multirow[t]{2}{*}{ Variable } & \multicolumn{2}{|l|}{ Total Effect } \\
\hline & Coef. Correlation & $t$-Statistics \\
\hline Perceived Risk $\left(\mathrm{X}_{1}\right)$-> Continuous Usage Intention $\left(\mathrm{Y}_{2}\right)$ & -0.650 & 12.485 \\
\hline Subjective Norm $\left(\mathrm{X}_{2}\right)$-> Continuous Usage Intention $\left(\mathrm{Y}_{2}\right)$ & 0.121 & 1.455 \\
\hline Perceived Risk $\left(\mathrm{X}_{1}\right)->$ trust $\left(\mathrm{Y}_{1}\right)$ & -0.625 & 13.767 \\
\hline Subjective Norm $\left(\mathrm{X}_{2}\right)$-> Trust $\left(\mathrm{Y}_{1}\right)$ & 0.193 & 2.330 \\
\hline Trust $\left(\mathrm{Y}_{1}\right)->$ Continuous Usage Intention $\left(\mathrm{Y}_{2}\right)$ & 0.520 & 6.775 \\
\hline VAF -> Indirect Effect / Total effect $(-0.325 /-0.650)$ & 0.500 & \\
\hline VAF -> Indirect Effect / Total Effect $(0,101 / 0,121)$ & 0.836 & \\
\hline
\end{tabular}

Source: Primary data processed, 2020.

The effect of subjective norm on continuous usage intention. The results of this study prove that subjective norm has a positive and insignificant effect on continuous usage intention. The main cause of this inequality of results is that one of the indicators of the subjective norm is that users who do not consider their parents' opinions are relatively low in giving subjective input in their decision making using GoPay. The results of this study are not statistically convincing, maybe if the level of significance is increased above $5 \%$ (level of significance) then of course the results will be different. The results of this study are not inconsistent with the concept, but if the causal indicators in the formation of latent variables (subjective norm) all contribute strongly, it can be assumed that the results will have a very significant effect on continuous usage intention. Although the results of subjective norm have a positive and insignificant effect on continuous usage intention, it turns out that this study has the same direction as the research conducted by Ayudya and Wibowo (2018), which states that subjective norms have no effect on the intention to use e-money, this is because There are many important people around respondents who know e-money so that respondents do not feel that important people around them encourage them to use e-money. The lowest indicator value in this study is social pressure from parents, so subjective norm has a positive and insignificant effect on continuous usage intention. The results of this study also state that in the same direction and in accordance with the results of previous studies by Bagozzi and Lee (2002) that voluntary participation and relatively low costs in using online, subjective norms play a less influential role in determining online user behavior. This research is similar and is supported by Lai and Zhao (2019) 's research that shows that subjective norms have a positive but insignificant effect on students' intentions in using ereading applications, in their research it states that this inequality is caused by students' 
intention to continue using the e-reading application. -reading is not so driven by their social environment but because of their need to use e-reading applications. The results of this study are also supported by research by Yang (2019) and Shankar and Datta (2018), which state that subjective norms have a positive but insignificant effect on continuous usage intention.

In addition to several unidirectional studies, there is also conflicting research conducted by Hong (2018), which states that subjective norms have a positive and significant effect on continued use of social networking sites. The reason is that people use the internet and smartphones to build relationships with other individuals or groups at all times, so that the social pressure they feel will influence their behavior to continue using social networking sites. Several studies conducted by Abdullateef et al. (2017) and Hossain et al. (2019) also provide results that subjective norms have a positive and significant effect on continuous usage intention. So that there is an insignificant influence in this study, because some indicators of subjective norm as a cause strengthen their influence on continuous usage intention, which is less important for using GoPay in Denpasar.

The effect of perceived risk on trust. The results show that perceived risk has a negative and significant effect on trust. This means that the higher the perceived risk felt by GoPay users, the lower user trust will be, and vice versa.. These results indicate that the values contained in perceived risk have a significant impact on GoPay user trust. Perceived risk which is measured based on indicators: transaction information leakage, malfunction, risk of losing money, and hacking as acceptable are proven to be able to influence GoPay user trust. This finding can be interpreted that if a user feels there is a risk of leaking transaction information, there is a risk of malfunction, there is a risk of losing money, and there is a risk of hacking, then this can make a significant contribution in reducing trust in GoPay users. The results of this study are in accordance with the results of previous studies by D'Alessandro et al. (2012), namely the lower the user's perceived risk, the higher the user's trust. Previous research conducted by Abdul-Hamid et al. (2019), Chang et al. (2017), Hong et al. (2015) and Nakayama et al. (2016) provide results that perceived risk has a negative and significant effect on trust. In addition, Kim and Benbasat (2006) mention the risk related to trust because the less risk encourages trust in e-commerce, whereas this research contradicts the research conducted by Nguyen and Huynh (2018) which gives a result that perceived risk has a negative effect but does not significant to trust.

The effect of subjective norms on trust. The analysis result shows that subjective norm has a positive and significant effect on trustworthiness. This means that the higher the subjective norm of GoPay users, the more user trust will be. Likewise, the lower the subjective norm of GoPay users, the more user trust will be increased. These results indicate that the values contained in subjective norms have a significant impact on GoPay user trust. Subjective norms measured based on indicators: parents, close friends, and other parties deemed important are proven to be able to influence the trust of GoPay users. This finding can be interpreted that if users consider the opinions of parents, close friends, and other parties who are considered important, then this will be able to make a significant contribution in increasing trust in GoPay users. The results of this study are consistent with the results of previous studies by Hitosugi (2011) who found that subjective norms play an important role in online trust formation. These results are also consistent with research by Ho et al. (2017) stated that subjective norm has a positive and significant effect on trust. These results are also supported by research conducted by Kusumawardhani et al. (2019) regarding green subjective norm also has a positive and significant effect on green trust.

The effect of trust on continuous usage intention. The results of the analysis show that trust has a positive and significant effect on continuous usage intention. This means that the higher the trust of GoPay users, the more continuous usage intention of users will be. Likewise, the lower the trust of GoPay users, the more continuous usage intention of users will be. These results indicate that the values contained in trust have a significant impact on the continuous usage intention of GoPay users. Trust that is measured based on indicators: user privacy, misuse of personal data, and security from breaches are proven to be able to affect the continuous usage intention of GoPay users. These findings can be interpreted that 
if users believe that GoPay can maintain user privacy, does not abuse personal data, and is safe from tampering, then this can make a significant contribution in increasing the continuous usage intention of GoPay users. The results of this study are in accordance with the results of previous research by Yan and Yang (2015) which states that trust has a positive and significant effect on continued use intention. These results are also in accordance with previous studies by Gao and Waechter (2017) that trust is an important antecedent of an individual's continued use intention in the context of mobile payment. These results are also consistent with research by Zhou and Li (2014) which shows that consumer confidence in mobile payments has an important effect on their intention to continue using this service. These results are also consistent with research conducted by Zhou and $\mathrm{Li}$ (2014) examining how to build trust which has a positive and significant effect on the intention to use and sustainable adoption of social media. These results are also consistent with research from Chang et al. (2017) and Wang and Lin (2017) state that trust has a positive and significant effect on continuous usage intention. The results of this study contradict research conducted by Susanto et al. (2016) who show that trust has a positive but insignificant effect on continuous usage intention.

The role of trust in mediating the effect of perceived risk on continuous usage intention. The results of the analysis show that trust is able to mediate the effect of perceived risk on continuous usage intention. Trust in this study is as a partial mediation. Based on these results, it can be concluded that the higher the perceived risk is, the lower the trust, so that in the end the user's continuous usage intention decreases. The results of this study are supported by research by Hong et al. (2015) and Nakayama et al. (2016) which states that perceived risk has a negative and significant effect on trust. The results of research on the effect of trust on continuous usage intention are also supported by research by Zhou and Li (2014), Chang et al. (2017) and Wang and Lin (2017).

The role of trust in mediating the effect of subjective norms on continuous usage intention. The results of the analysis show that trust is able to mediate the effect of subjective norms on continuous usage intention. Trust in this study is a full mediation (full mediation). Based on these results, it can be interpreted that the higher the perceived subjective norm will increase trust, so that in the end the user's continuous usage intention will increase. The results of this study support the previous study by Hitosugi (2011) which found that subjective norms play an important role in online trust formation. Research conducted by Susanto et al. (2015) provide results that trust has a positive and significant effect on continuous usage intention. The results of this study also support the research conducted by Gong et al. (2019) found that trust mediates the relationship between subjective norm and continuous usage intention.

Limitations. The process of writing this study has several limitations that need to be noted for future studies. Some of these limitations, among others, are that the scope of the research is only limited to the GoPay e-wallet, thus the results of the research may also have differences regarding perceptions or interpretations of each respondent in other e-wallets. This research is limited to examining the variables of perceived risk, subjective norm, trust, and continuous usage intention, thus it cannot further examine the factors outside of these variables. This study uses a cross-sectional time plan or at a certain point in time, but on the other hand this study observes the dynamics of conditions that change over time, therefore this research is important to re-examine in the future.

\section{CONCLUSION AND SUGGESTIONS}

Based on the results of the research analysis, the conclusion of this study is that perceived risk has a negative and significant effect on continuous usage intention of GoPay users. Subjective norms have a positive and insignificant effect on continuous usage intention of GoPay users. This means that if the user's subjective norm is increasing, the user's continuous usage intention in using GoPay will not necessarily increase. Perceived risk has a negative and significant effect on GoPay user trust. Subjective norms have a positive and significant effect on GoPay user trust. Trust has a positive and significant effect 
on continuous usage intention of GoPay users. This means that if trust increases, the continuous usage intention of users to use GoPay will increase as well. Trust is able to mediate the effect of perceived risk on continuous usage intention of GoPay users. This shows that the perceived risk of GoPay users will have a significant impact on the user's continuous usage intention if it is mediated by trust, which means that the continuous usage intention of GoPay users is highly dependent on the level of perceived risk that is perceived by the user and also the level of trust. Trust is able to mediate the effect of subjective norms on continuous usage intention of GoPay users. This shows that GoPay user subjective norm will have a significant impact on user's continuous usage intention if it is mediated by trust, which means that the continuous usage intention of GoPay users is highly dependent on the user's subjective norm level and also the level of trust.

Based on the results of research analysis, we suggest some points for GoPay management in increasing continuous usage intention of GoPay users, that is: increasing trust by always maintaining user's personal data and socializing that GoPay does not use user's personal data for other things, such as trading it with third partie and strengthening the system so that users will increasingly believe that their funds in GoPay account are safe from tampering. Subsequent research can add constructs other than perceived risk and subjective norms to be able to identify more deeply about belief and continuous usage intention, for example perceived value, perceived ease of use, and attitudes.

\section{REFERENCES}

1. Abdul-Hamid, I. K., Shaikh, A. A., Boateng, H., \& Hinson, R. E. (2019). Customers' Perceived Risk and Trust in Using Mobile Money Services-an Empirical Study of Ghana. International Journal of E-Business Research (IJEBR), 15 (1), 1-19.

2. Abdullateef, A.O., Iwu, C.G., Kareem, O., \& Manzuma-Ndaaba, N.M. (2017). Determining customer continuous online usage intention in the airline industry. Research and investment management implications. Innovative Marketing , 11 (1), 17-27.

3. Ayudya, A. C., \& Wibowo, A. (2018). The intention to use e-money using theory of planned behavior and locus of control. Jurnal Keuangan dan Perbankan, 22(2), 335-349.

4. Badan Pusat Statistik Provinsi Bali. (2019). Persentase Penduduk Usia 5 Tahun ke Atas yang Mengakses Teknologi Informasi dan Komunikasi (TIK) dalam 3 Bulan Terakhir Menurut Kabupaten/Kota. https://bali.bps.go.id/statictable/2018/04/13/95/persentasependuduk-usia-5-tahun-ke-atas-yang-mengakses-teknologi-informasi-dan-komunikasi-tikdalam-3-bulan-terakhir-menurut-kabupaten-kota-2019.html. Diakses tanggal 19 Juli 2020 pukul 11.00

5. Bagozzi, R. P., and Lee, K. H. (2002). Multiple routes for social influence: The role of compliance, internalization, and social identity. Social Psychology Quarterly, 226-247.

6. Bapna, R., Gupta, A., Rice, S., \& Sundararajan, A. (2017). Trust and the Strength of Ties in Online Social Networks: An Exploratory Field Experiment. MIS Q., 41(1), 115-130.

7. Beldad, A. D., and Hegner, S. M. (2018). Expanding the technology acceptance model with the inclusion of trust, social influence, and health valuation to determine the predictors of German users' willingness to continue using a fitness app: A structural equation modeling approach. International Journal of Human-Computer Interaction, 34 (9), 882-893.

8. Beritagar.id. (2019). Penetrasi internet di Bali paling tinggi. https://beritagar.id/artikel/berita/penetrasi-internet-di-bali-paling-tinggi (diakses tanggal 16 Desember 2019, pukul 08.56 WITA)

9. Bagozzi, R. P., \& Lee, K. H. (2002). Multiple routes for social influence: The role of compliance, internalization, and social identity. Social Psychology Quarterly, 226-247.

10. Baraja, Y. A., \& Gunawan, J. (2020). Identifikasi Karakteristik Merchant dalam Mengadopsi Layanan Mobile Payment Studi Kasus: Merchant OVO dan Merchant Gopay di Surabaya. Jurnal Sains dan Seni ITS, 8(2), D405-D410.

11. Chang, S. E., Liu, A. Y., and Shen, W. C. (2017). User trust in social networking services: A comparison of Facebook and Linkedln. Computers in Human Behavior, 69, 207-217. 
12. Chang, Y. P., \& Zhu, D. H. (2011). Understanding social networking sites adoption in China: A comparison of pre-adoption and post-adoption. Computers in Human behavior, 27 (5), 1840-1848.

13. Chen, Y. F. (2014). See you on Facebook: exploring influences on Facebook continuous usage. Behaviour \& Information Technology, 33 (11), 1208-1218.

14. Cheung, C. M., and Lee, M. K. (2010). A theoretical model of intentional social action in online social networks. Decision support systems, 49 (1), 24-30.

15. D'Alessandro, S., Girardi, A., and Tiangsoongnern, L. (2012). Perceived risk and trust as antecedents of online purchasing behavior in the USA gemstone industry. Asia pacific journal of marketing and logistics. 24 (3). $433-460$

16. Davis, F. D., Bagozzi, R. P., and Warshaw P. R. (1989). User acceptance of computer technology: a comparison of two theoretical models. Management Science, 35 (8). pp. 982-1002

17. Dwivedi, Y. K., Rana, N. P., Jeyaraj, A., Clement, M., \& Williams, M. D. (2019). Reexamining the unified theory of acceptance and use of technology (UTAUT): Towards a revised theoretical model. Information Systems Frontiers, 21(3), 719-734.

18. Gao, L., \& Waechter, K. A. (2017). Examining the role of initial trust in user adoption of mobile payment services: an empirical investigation. Information Systems Frontiers, 19(3), 525-548.

19. Gao, S., Yang, X., Guo, H., \& Jing, J. (2018). An empirical study on users' continuous usage intention of $Q R$ code mobile payment services in China. International Journal of $E$ Adoption (IJEA), 10(1), 18-33.

20. Goh, S. W. (2017). Factors affecting adoption of e-payment among private university students in Klang Valley (Doctoral dissertation, UTAR).

21. Gong, Z., Han, Z., Li, X., Yu, C., and Reinhardt, J. D. (2019). Factors influencing the adoption of online health consultation services: the role of subjective norm, trust, perceived benefit and offline habit. Frontiers in public health, 7, 286.

22. Hanafizadeh, P., Behboudi, M., Koshksaray, A. A., and Tabar, M. J. S. (2014). Mobilebanking adoption by Iranian bank clients. Telematics and Informatics, 31(1), 62-78.

23. Hepola, J., Karjaluoto, H., and Shaikh, A. A. (2016). Consumer engagement and behavioral intention toward continuous use of innovative mobile banking applications: a case study of Finland. In ICIS 2016: Proceedings the Thirty Seventh International Conference on Information Systems. Digital Innovation at the Crossroads, ISBN 978-09966831-3-5. Association for Information Systems (AIS).

24. Hitosugi, K. (2011). Trust on the web: the power of subjective norm across cultures. University of Hawaii at Manoa.[On-line]. Available at URL: http://clairehweebly.com/uploads/5/2/9/9/5299882/hitosugi_sninonlinetrust_crossculturec onf_dec2011.pdf [Accessed December14th, 2019].

25. Hong, J., Lee, O. K., and Suh, W. (2013). A study of the continuous usage intention of social software in the context of instant messaging. Online Information Review, 37(5), 692-710.

26. Hong, C., C. Kim, K. J. Kim, and S. Kim. (2015). A Polymorphic Service Management Scheme Based on Virtual Object for Ubiquitous Computing Environment. Multimedia Tools and Applications 74 (16): 6183-6196.

27. Hong, I. B. (2018). Social and personal dimensions as predictors of sustainable intention to use Facebook in Korea: An empirical analysis., Sustainability, 10 (8), 2856.

28. Hossain, M., \& Kim, M. (2018). Does Multidimensional Service Quality Generate Sustainable Use Intention for Facebook?. Sustainability, 10 (7), 2283.

29. Hossain, M. A. (2019). Effects of uses and gratifications on social media use: The Facebook case with multiple mediator analysis. PSU Research Review, 3(1), 16-28.

30. Hossain, M., Kim, M., and Jahan, N. (2019). Can "Liking" Behavior Lead to Usage Intention on Facebook? Uses and Gratification Theory Perspective., Sustainability, 11 (4), 1166. 
31. IDN Financials. (2020). Transaksi digital di Gopay mencapai US $\$ 6,3$ miliar. https://www.idnfinancials.com/id/news/31591/gopay-recorded-total-transaction. Diakses tanggal 21 Juli 2020 pukul 10.34

32. IPrice. (2020). Siapa Aplikasi E-wallet dengan Pengguna Terbanyak di Indonesia?. https://iprice.co.id/trend/insights/e-wallet-terbaik-di-indonesia/ Diakses tanggal 21 Juli 2020 pukul 10.38

33. Jayantari, I. A. A. U., dan Seminari, N. K. (2018). Peran Kepercayaan Memediasi Persepsi Risiko terhadap Niat Menggunakan Mandiri Mobile Banking di Kota Denpasar. E-Jurnal Manajemen Universitas Udayana, 7 (5).

34. Kata Data. (2019). Transaksi Tembus Rp 89,5 Triliun, Pengguna Aktif GoPay Terbanyak di RI. https://katadata.co.id/desysetyowati/digital/5e9a50396948f/transaksi-tembus-rp895-triliun-pengguna-aktif-gopay-terbanyak-di-ri. Diakses tanggal 20 Juli 2020 pukul 11.01

35. Keith, M. J., Babb, J., Furner, C., Abdullat, A., \& Lowry, P. B. (2016). Limited information and quick decisions: consumer privacy calculus for mobile applications. AIS Transactions on Human-Computer Interaction (THCl), 8(3), 88-130.

36. Kompas. (2020). Jadi Andalan, 5 Layanan Gojek Meningkat Penggunaannya Selama Pandemi. $\quad$ https://money.kompas.com/read/2020/07/13/184100626/jadi-andalan-5layanan-gojek-meningkat-penggunaannya-selama-pandemi. Diakses tanggal 20 Juli 2020 pukul 11.01

37. Kusumawardhani, A., Batu, K. L., \& Aqmala, D. (2019). How Green should Trust, Norm and Attitude be Colored? An Empirical Research in Asian Market Consumers. Calitatea, 20(168), 118-126.

38. Li, H., \& Liu, Y. (2014). Understanding post-adoption behaviors of e-service users in the context of online travel services. Information \& Management, 51(8), 1043-1052.

39. Lokadata. (2019). Penetrasi internet di Bali paling tinggi. https://lokadata.id/artikel/penetrasi-internet-di-bali-paling-tinggi. Diakses tanggal 20 Juli 2020 pukul 10.55

40. Nabavi, A., Taghavi-Fard, M. T., Hanafizadeh, P., \& Taghva, M. R. (2016). Information technology continuance intention: a systematic literature review. International Journal of E-Business Research (IJEBR), 12(1), 58-95.

41. Nakayama, M., Medlin, B. D., Chen, C., \& Vannoy, S. A. (2016). Key factors increasing the trust and intention to adopt standard cloud-based applications. In Pacific Asia Conference On Information Systems (PACIS). Association For Information System.

42. Nguyen, T. D., \& Huynh, P. A. (2018, January). The roles of perceived risk and trust on e-payment adoption. In International Econometric Conference of Vietnam, (pp. 926-940). Springer, Cham.

43. Park, S. T., \& Oh, M. R. (2019). An empirical study on the influential factors affecting continuous usage of mobile cloud service. Cluster Computing, 22(1), 1873-1887.

44. Pavlou, P. A., \& Ratnasingam, P. (2003). Technology trust in B2B electronic commerce: conceptual foundations. Business strategies for information technology management (pp. 200-215).

45. Pavlou, P. A., \& Dimoka, A. (2006). The nature and role of feedback text comments in online marketplaces: Implications for trust building, price premiums, and seller differentiation. Information Systems Research, 17 (4), 392-414.

46. Pinem, R. J. (2020). Gopay As a Practical Payment Tool For Millennial Generations In The Digital Era. Journal of Applied Business Administration, 4(2), 206-211.

47. Rahman, S.: (2014), Introduction to E-Commerce Technology in Business. GRIN

48. Rahyuda, K. (2017). Metode Penelitian Bisnis. Denpasar: Udayana University Press

49. Salleh, S., \& Laxman, K. (2015). Examining the Effect of External Factors and ContextDependent Beliefs of Teachers in the Use of ICT in Teaching: Using an Elaborated Theory of Planned Behavior. Journal of Educational Technology Systems, 43 (3), 289319.

50. Salehan, M., Mousavizadeh Kashipaz, S. M., \& Xu, C. (2013). Information sharing on social networking websites: antecedents and consequences of trust. Proceedings of the 
Nineteenth Americas Conference on Information Systems, Chicago, Illinois, August 1517, 2013.

51. Shankar, A., dan Datta, B. (2018). Factors affecting mobile payment adoption intention: An Indian perspective. Global Business Review, 19(3_suppl), S72-S89.

52. Shiue, Y. M., Hsu, Y. C., \& Liang, Y. C. (2017, May). Modeling the continuance usage intention of game-based learning in the context of collaborative learning. In 2017 International Conference on Applied System Innovation (ICASI) (pp. 1106-1109). IEEE.

53. Subagio, H dan Jessica, J. (2020). Pengaruh Perceived Usefulness, Perceived Ease Of Use, Subjective Norm, Dan Customer Experience Terhadap Intention To Use Mytelkomsel (Studi Kasus Pada Mahasiswa Universitas Kristen Petra Surabaya). Jurnal Strategi Pemasaran, 7 (1).

54. Susanto, A., Chang, Y., \& Ha, Y. (2016). Determinants of continuance intention to use the smartphone banking services: an extension to the expectation-confirmation model. Industrial Management \& Data Systems, 116 (3), 508-525.

55. Veeramootoo, N., Nunkoo, R., \& Dwivedi, Y. K. (2018). What determines success of an e-government service? Validation of an integrative model of e-filing continuance usage. Government information quarterly, 35(2), 161-174.

56. Wang, Y. S., Wu, S. C., Lin, H. H., Wang, Y. M., \& He, T. R. (2012). Determinants of user adoption of web"Automatic Teller Machines': an integrated model of'Transaction Cost Theory'and'Innovation Diffusion Theory'. The Service Industries Journal, 32(9), 15051525.

57. Wang, J. (2016, December). The Empirical Research on the Continuous Usage Intention of Mobile Internet Users. In 2016 4th International Conference on Electrical \& Electronics Engineering and Computer Science (ICEEECS 2016). Atlantis Press.

58. Wang, E. S. T., \& Chou, N. P. Y. (2016). Examining social influence factors affecting consumer continuous usage intention for mobile social networking applications. Int. J. Mobile Communications, 14 (1).

59. Wang, E. S. T., \& Lin, R. L. (2017). Perceived quality factors of location-based apps on trust, perceived privacy risk, and continuous usage intention. Behaviour \& Information Technology, 36 (1), 2-10.

60. Warta Ekonomi. (2019). Go-Jek dan Go-Pay Jalin Kerja Sama dengan Pemkot Denpasar. https://www.wartaekonomi.co.id/read220778/go-jek-dan-go-pay-jalin-kerjasama-dengan-pemkot-denpasar.html. diakses tanggal 16 Juli 2020, pukul 16.00

61. Williams, M. D., Rana, N. P., \& Dwivedi, Y. K. (2012). A bibliometric analysis of articles citing the unified theory of acceptance and use of technology. In Information Systems Theory (pp. 37-62). Springer, New York, NY.

62. Yang, Q., Pang, C., Liu, L., Yen, D. C., \& Tarn, J. M. (2015). Exploring consumer perceived risk and trust for online payments: An empirical study in China's younger generation. Computers in Human Behavior, 50, 9-24.

63. Yang, X. (2019). Social influence or personal attitudes? Understanding users' social network sites continuance intention. Kybernetes, 48(3), 424-437.

64. Yoon, C., \& Rolland, E. (2015). Understanding continuance use in social networking services. Journal of Computer Information Systems, 55(2), 1-8.

65. Zhou, Z., Fang, Y., Vogel, D., Jin, X.-L., \& Zhang, X. (2012). Attracted to or locked in? Predicting intention in social virtual world services. Journal of Management of Information Systems,29 (1),273- 306.

66. Zhou, T., \& Li, H. (2014). Understanding mobile SNS continuance usage in China from the perspectives of social influence and privacy concern. Computers in Human Behavior, 37, 283-289.

67. Zhu, D. H., Lan, L. Y., \& Chang, Y. P. (2017). Understanding the Intention to Continue Use of a Mobile Payment Provider: An Examination of Alipay Wallet in China. International Journal of Business \& Information, 12 (4). 